\title{
A spongin-boring $\alpha$-proteobacterium is the etiological agent of disease in the Great Barrier Reef sponge Rhopaloeides odorabile
}

\author{
Nicole S. Webster ${ }^{1,2, *}$, Andrew P. Negri ${ }^{1}$, Richard I. Webb ${ }^{3}$, Russell T. Hill ${ }^{4}$ \\ ${ }^{1}$ Australian Institute of Marine Science, Townsville, Queensland 4810, Australia \\ ${ }^{2}$ Department of Microbiology, James Cook University, Townsville, Queensland 4810, Australia \\ ${ }^{3}$ Centre for Microscopy and Microanalysis, University of Queensland, St. Lucia, Queensland 4072, Australia \\ ${ }^{4}$ Center of Marine Biotechnology, University of Maryland, Baltimore, Maryland 21223, USA
}

\begin{abstract}
High levels of mortality in the Mediterranean bath sponge industry have raised concerns for the future of sponge farms. Healthy sponges feed predominantly on bacteria, and many harbour a wide diversity of inter- and extra-cellular symbiotic bacteria. Here we describe the first isolation and description of a pathogenic bacterium from an infected marine sponge. Microbiological examination of tissue necrosis in the Great Barrier Reef sponge Rhopaloeides odorabile resulted in isolation of the bacterial strain NW4327. Sponges infected with strain NW4327 exhibited high levels of external tissue necrosis, and the strain was re-isolated from infected sponges. A single morphotype, which had burrowed through the collagenous spongin fibres causing severe necrosis, was observed microscopically. Strain NW4327 was capable of degrading commercial preparations of azo-collagen, providing further evidence of its involvement in spongin fibre necrosis. Strain NW4327 disrupted the microbial community associated with $R$. odorabile and was able to infect and kill healthy sponge tissue. 16S rRNA sequence analysis revealed that strain NW4327 is a novel member of the $\alpha$-proteobacteria.
\end{abstract}

KEY WORDS: Sponge $\cdot$ Disease $\cdot$ Pathogen $\cdot$ Spongin $\cdot$ Coral reef

Resale or republication not permitted without written consent of the publisher

Until recently, the Mediterranean commercial sponge fishery maintained an economically important output averaging about $100 \mathrm{t} \mathrm{yr}^{-1}$. In 1986 catastrophic sponge mortalities in the eastern Mediterranean reduced the annual output to only a few tonnes (Vacelet 1994). The Mediterranean sponges exhibited fragile and brittle skeletons that crumbled under water (Vacelet 1994). Gaino \& Pronzato (1989) performed a microscopic evaluation of diseased sponge tissue and observed a bacterium that burrowed through the spongin fibres

*E-mail: n.webster@aims.gov.au causing significant necrosis. Subsequent analysis by Vacelet et al. (1994) revealed that bacterial attack could originate in areas of living sponge tissue, suggesting that the bacterium may be the primary pathogen; however, isolation of the pathogen in these studies was not successful. Sponge mortality has also been attributed to cyanobacteria (Rützler 1988) and localised lesions have been ascribed to viruses (Vacelet \& Gallissian 1978) and fungi (Galstoff 1942). Rhopaloeides odorabile is a dictyoceratid sponge common throughout the Great Barrier Reef region. Previous research has reported a dense and diverse microbial community associated with healthy sponges of this species (Webster \& Hill 2001, Webster et al. 2001a, b). Cultivation analysis of the heterotrophic bacterial community associated with $R$. odorabile revealed the predominance of a single $\alpha$-proteobacterium symbiont, strain NW001, that was ubiquitous in all healthy individual sponges (Webster \& Hill 2001). This study aimed to examine the aetiological role of bacteria in the sponge disease process using $R$. odorabile as a model system.

Materials and methods. Pathogenicity trial: In 1998, a heavily fouled and necrotic specimen of Rhopaloeides odorabile was observed at a water depth of $8 \mathrm{~m}$ on Davies Reef (Great Barrier Reef, 1850.24'S, $\left.147^{\circ} 37.59^{\prime} \mathrm{E}\right)$. Strain NW4327 was isolated in pure culture on Marine Agar 2216 (Difco Laboratories) from this sponge. Healthy sponge clones were experimentally infected with strain NW4327 to determine its aetiological role in the disease process. Clones $\left(8 \mathrm{~cm}^{3}\right)$ of a single healthy specimen of $R$. odorabile were maintained in a flow-through aquarium. A single sponge was used for the pathogenicity trial to avoid possible confounding genetic variability or inter-sponge fluctuations in health status. The clones were individually 
threaded onto flat plates of bleached coral skeleton, secured using stainless steel ties and allowed to heal for $2 \mathrm{wk}$ prior to infection. Sponge clones were placed in 801 plastic aquaria for each experimental dose. The putative pathogenic bacterium was infected in Marine Broth 2216 (Difco) at low, medium and high concentrations corresponding to $10^{2}, 10^{4}$ and $10^{6}$ colony-forming units (CFU) $\mathrm{ml}^{-1}$ as determined from direct plate counts and comparison of culture turbidity with McFarland standards. Controls were established for all treatments. During the infection process, the water flow was stopped, the appropriate inoculum of cells added to each treatment and the aquaria individually aerated for $5 \mathrm{~h}$ to allow the sponges to filter the $80 \mathrm{l}$ volume of seawater. During this time, there was no detectable change in temperature of the aquarium water $\left(27.5\right.$ to $\left.28.2^{\circ} \mathrm{C}\right)$. After a $5 \mathrm{~h}$ exposure, the water flow was re-started. The trial was conducted over $14 \mathrm{~d}$, and at completion, visual observations of the extent of external necrosis and epifouling were recorded.

Electron microscopy: Sections of sponge tissue from the $10^{6} \mathrm{CFU} \mathrm{ml}{ }^{-1}$ treatment (approx. $1 \mathrm{~mm}$ diameter) were removed after $14 \mathrm{~d}$ and processed as described in Webster \& Hill (2001).

Collagenase activity: The ability of strain NW4327 to degrade collagen was determined in a digestion experiment using azo dye-impregnated collagen (Azocoll, Sigma). Freeze-dried, washed, sterile Azocoll was suspended in $20 \mathrm{ml}$ of sterile 9:1 seawater:marine broth to a final concentration of $1 \mathrm{mg} \mathrm{ml}^{-1}$. The suspensions were inoculated with $4 \times 10^{3}$ cells ml ${ }^{-1}$ strain NW4327 in an incubator shaker at $120 \mathrm{rpm}$. Sub-samples $(2 \mathrm{ml})$ were transferred to $10 \mathrm{ml}$ tubes periodically and centrifuged for $2 \mathrm{~min}$ at $12000 \times g$ to pellet bacteria and residual collagen. The absorbance of supernatants was measured at $520 \mathrm{~nm}$ to determine the concentration of dye released by bacterial digestion (Chavira et al. 1984). Control incubations containing only Marine Broth 2216 were analysed using the same procedure.

DNA extraction, PCR and sequence analysis: Strain NW4327 was identified by 16S rRNA sequence analysis by the procedure described in Webster \& Hill (2001).

Results and discussion. The tissue of the naturally occurring diseased sponge was soft and fragile with large portions of pinacoderm and external tissue eroded away to reveal the collagenous skeletal fibres. Similar symptoms have previously been described for diseased Mediterranean sponges (Vacelet 1994). Cultivation of bacteria from this sponge revealed an absence of the dominant culturable symbiont, strain NW001 (Webster \& Hill 2001), and instead a single bacterium designated strain NW4327 was isolated in pure culture. The initial isolation of strain NW4327, however, did not provide conclusive evidence of the aetiological role of this bacterium in disease establish- ment. It is possible that as sponges became moribund, opportunistic bacteria were able to proliferate to high cell densities, out-competing the normal spongeassociated microbiota.

The symptoms described for the infected sponge in situ were experimentally induced in clones following passive infection with strain NW4327. When exposed to doses of $10^{2}, 10^{4}$ and $10^{6} \mathrm{CFU} \mathrm{ml}^{-1}$, clones exhibited $20 \%, 55 \%$ and $90 \%$ external tissue necrosis, respectively (Fig. 1). The extent of necrosis rose linearly with the concentration of the inoculum $\left(\mathrm{r}^{2}=0.98\right)$ and was significantly higher in all inoculations than in the Day 14 controls, which exhibited almost no fouling or necrosis after $14 \mathrm{~d}(\mathrm{p}<0.0001, \mathrm{df}=3,8, F=9.9)$. In all treatments, the infected clones became fouled with epiphytic algae and a significant correlation existed between the concentration of the infective dose and the extent of fouling $\left(\mathrm{r}^{2}=0.93\right)$ with total cover ranging from 13 to $90 \%$ (Fig. 1). The extent of fouling was significantly higher in all infection treatments $(\mathrm{p}<0.0001$, $\mathrm{df}=3,8, F=125.1$ ) except for the low dose treatment.

In healthy specimens of Rhopaloeides odorabile, strain NW001 constitutes between 70 and $95 \%$ of the total culturable community (Webster \& Hill 2001), and this relationship held for control sponges in the pathogenicity trial. However, when $R$. odorabile was infected with $10^{2}, 10^{4}$ and $10^{6} \mathrm{CFU} \mathrm{ml} \mathrm{m}^{-1}$ doses of strain NW4327, strain NW001 disappeared and strain NW4327 dominated the culturable bacterial community after $14 \mathrm{~d}$ (Table 1). The proportion of NW4327 reisolated was lower for the highest infection dose, and this was most likely due to the colonisation of the sponge matrix by other heterotrophic species after the degradation of spongin fibres. Strain NW4327 was reisolated from sponges at all infection doses, fulfilling

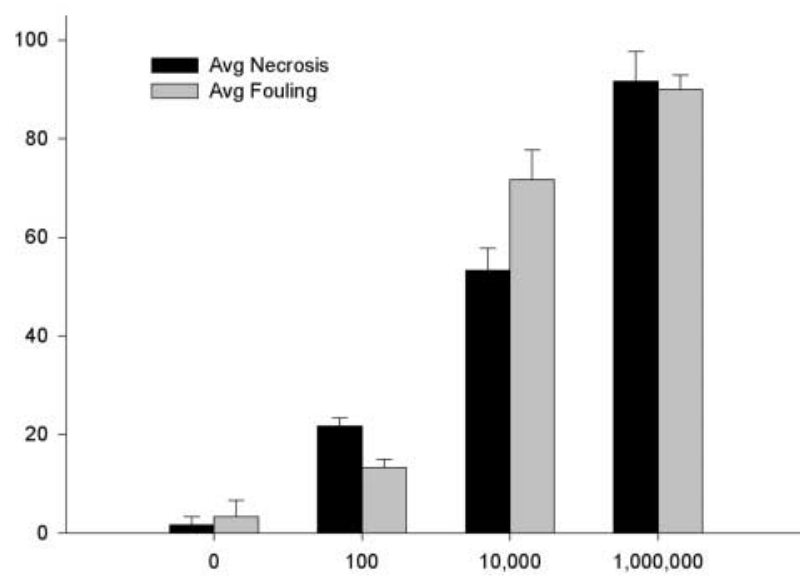

Fig. 1. Average sponge surface area $( \pm \mathrm{SE})$ affected by tissue necrosis and epiphytic algal fouling after infection with increasing experimental doses of strain NW4327. CFU: colony-forming units 

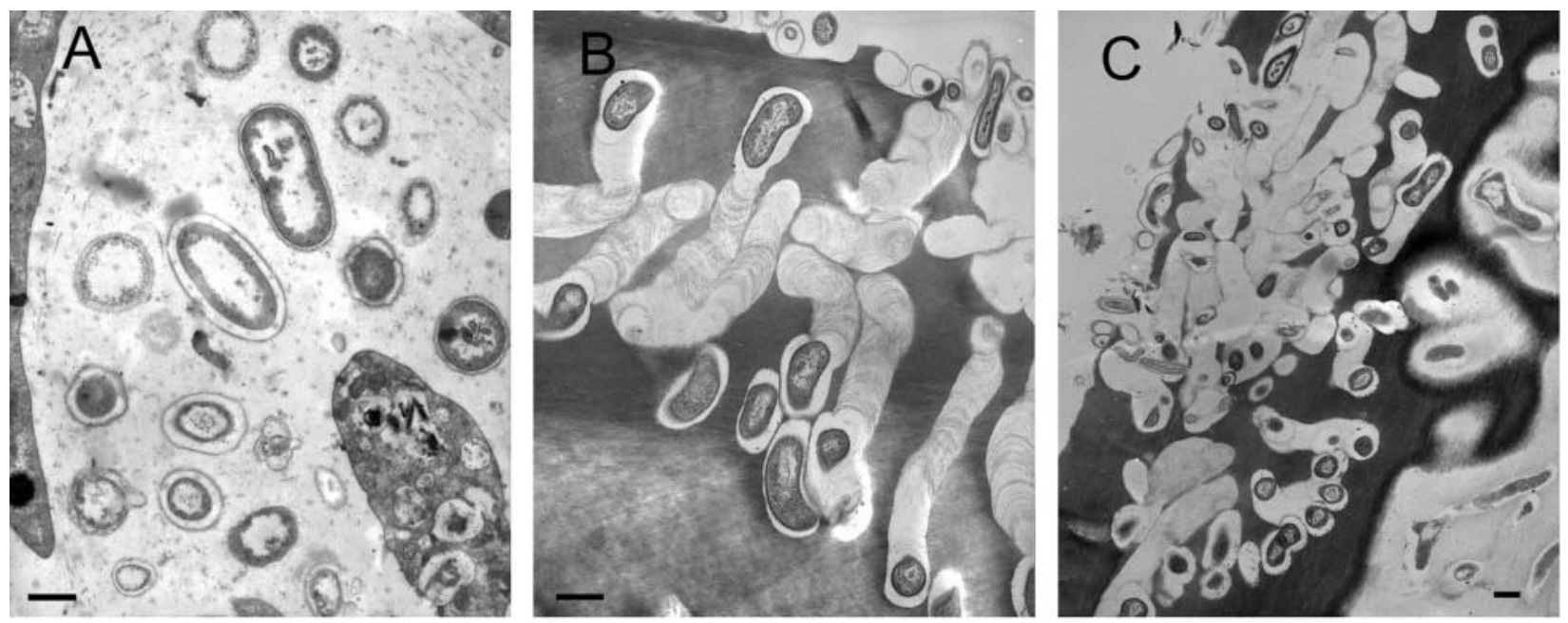

Fig. 2. Transmission electron micrographs revealing the diversity of bacterial morphotypes associated with control sponges (A) and sponges infected with $10^{6} \mathrm{CFU} \mathrm{ml}^{-1}$ of strain NW4327 (B) causing massive necrosis of the spongin tissue (C). The scale bar on all micrographs is $500 \mathrm{~nm}$

Koch's postulates and indicating that strain NW4327 is a primary sponge pathogen.

Electron micrographs showed that control sponges were host to a wide diversity of bacterial morphotypes (Fig. 2A), as described previously (Webster \& Hill 2001, Webster et al. 2001a). In contrast, sponges infected with strain NW4327 possessed a single predominant morphotype that burrowed through the collagenous spongin fibres (Fig. 2B) causing severe necrosis (Fig. 2C). Other morphotypes were occasionally observed throughout the sections of infected sponge tissue; however, these were never observed burrowing through the spongin fibres, and are likely to be components of the water column microbial community. Strain NW4327 completely degraded collagen in the form of Azocoll after $24 \mathrm{~h}$ incubation (Fig. 3), providing further evidence of the role of this bacterium in the pathogenic attack on sponge collagen.

During the 1986-1990 outbreak of commercial sponge disease in the Mediterranean, bacterial infec-

Table 1. Counts of total cultivated bacteria, symbiont strain NW001 and pathogen strain NW4327 following 14 d infection with increasing experimental doses of the pathogen. CFU: colony-forming units; T: time

\begin{tabular}{|lccc|}
\hline Treatment & $\begin{array}{c}\text { Total CFU ml } \\
\left(\times 10^{3}\right) \pm \mathrm{SE}\end{array}$ & $\begin{array}{c}\text { NW001 CFU ml } \\
\left(\times 10^{3}\right) \pm \mathrm{SE}\end{array}$ & $\begin{array}{c}\text { NW4327 CFU ml } \\
\left(\times 10^{3}\right) \pm \mathrm{SE}\end{array}$ \\
\hline Control $(\mathrm{T}=0 \mathrm{~d})$ & $98.7 \pm 9.2$ & $72.2 \pm 9.8$ & 0 \\
Control $(\mathrm{T}=14 \mathrm{~d})$ & $15.2 \pm 5.6$ & $11.0 \pm 3.1$ & 0 \\
NW4327 $\left(10^{2}\right)$ & $72.0 \pm 12.0$ & 0 & $43.1 \pm 6.1$ \\
NW4327 $\left(10^{4}\right)$ & $81.3 \pm 6.4$ & 0 & $67.8 \pm 12.7$ \\
NW4327 $\left(10^{6}\right)$ & $12.6 \pm 6.8$ & 0 & $0.30 \pm 0.08$ \\
\hline
\end{tabular}

tion of sponges and attack of collagenous skeletons was reported (Vacelet et al. 1994). In that study, electron micrographs revealed spongin-boring bacteria infecting dead, diseased and partially necrotic sponges. Infected tissue of Hippospongia communis, another dictyoceratid sponge, appears from the micrographs and description to be very similar to that observed in Rhopaloeides odorabile. The tunnelling pattern looks almost identical, and the canaliculi inside the fibres were from 0.4 to $0.8 \mu \mathrm{m}$ in diameter containing loose fibrils disposed in characteristic arched transverse bands, consistent with observations of infected $R$. odorabile tissue. In the sponges Ircinia sp. and Sarcotragus sp., only the collagenous filaments were attacked, and choanocyte chambers and symbiotic bacteria were still evident (Vacelet et al. 1994). In contrast, $R$. odorabile became entirely necrotic after infection with strain NW4327, and no other bacterial morphotypes were observed within the sections of spongin fibres. This may be partially due to the experimental dose with which $R$. odorabile was infected. However, these infection doses covered 4 orders of magnitude, from $10^{2}$ to $10^{6}$ cells $\mathrm{ml}^{-1}$, and all resulted in pathogenic symptoms. No previous microbial pathogenicity trials have been performed on sponges. In corals, Richardson et al. (1998) found that infection with a Sphingomonas sp. pathogen resulted in $10^{5}{\mathrm{cells} \mathrm{ml}^{-1}}^{-1}$ in diseased tissue, whereas cell counts from healthy coral tissue ranged from $10^{3}$ to $10^{4}$ cells $\mathrm{ml}^{-1}$. 


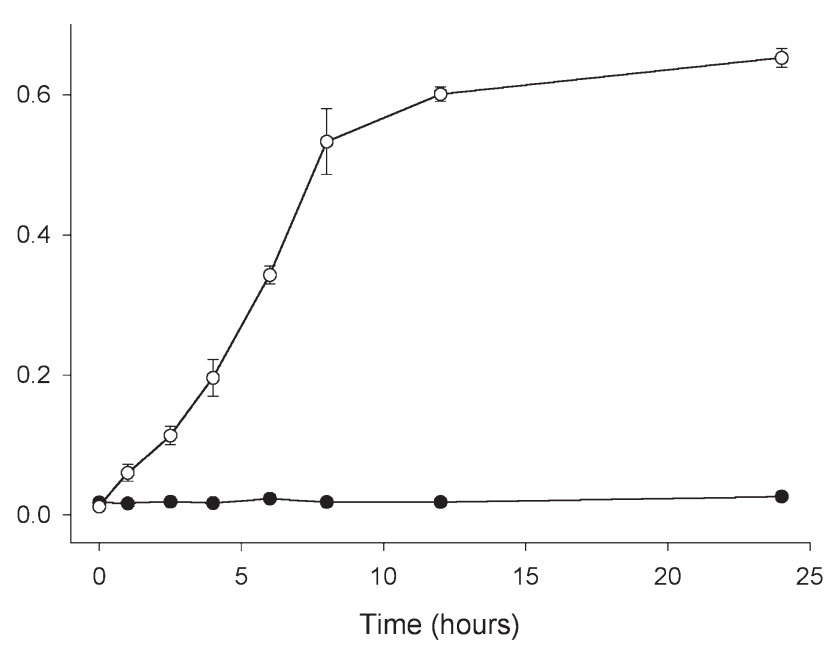

Fig. 3. The degradation of azo-collagen measured by absorbance at $520 \mathrm{~nm}$ during a $24 \mathrm{~h}$ incubation with strain NW4327 (O) and relevant control (

16S rRNA sequence analysis revealed that strain NW4327 is a novel member of the $\alpha$-proteobacteria, distantly related to Sulfitobacter pontiacus (94\% similarity based on 16S rRNA gene sequence; Fig. 4). S. pontiacus is a heterotrophic marine bacterium described from the Mediterranean and the Black Sea (Sorokin 1995, Pukall et al. 1999). This genus specialises in sulphite oxidation and has not previously been associated with pathogenic attack. A recent study reported significant larval oyster disease caused by a related member of the Roseobacter genus (Boettcher et al. 2000).

This is the first time that a bacterial pathogen has been isolated and confirmed as the primary cause of sponge disease. The similarities in symptoms and electron microscopic evidence between the infection that decimated the Mediterranean bath sponge industry and the attack on Rhopaloeides odorabile by strain NW4327 indicate that bacterial sponge disease may be a global phenomenon. Sponge farms are being established worldwide for production of bioactive natural products and cosmetic products. High density monocultures of a single sponge species in culture may be vulnerable to pathogenic attack by bacteria such as strain NW4327. Not only do bacteria have the potential to cause sponge mortality, but strains such as NW4327 and the strains responsible for mortality in the Mediterranean can potentially degrade spongin tissue, thereby destroying the commercially important fibrous structures of these organisms.

Acknowledgements. This work was supported by an Australian Postgraduate Award to N.S.W. This is Contribution No. 1094 of the Australian Institute of Marine Science and Contribution No. 553 of the Centre of Marine Biotechnology.

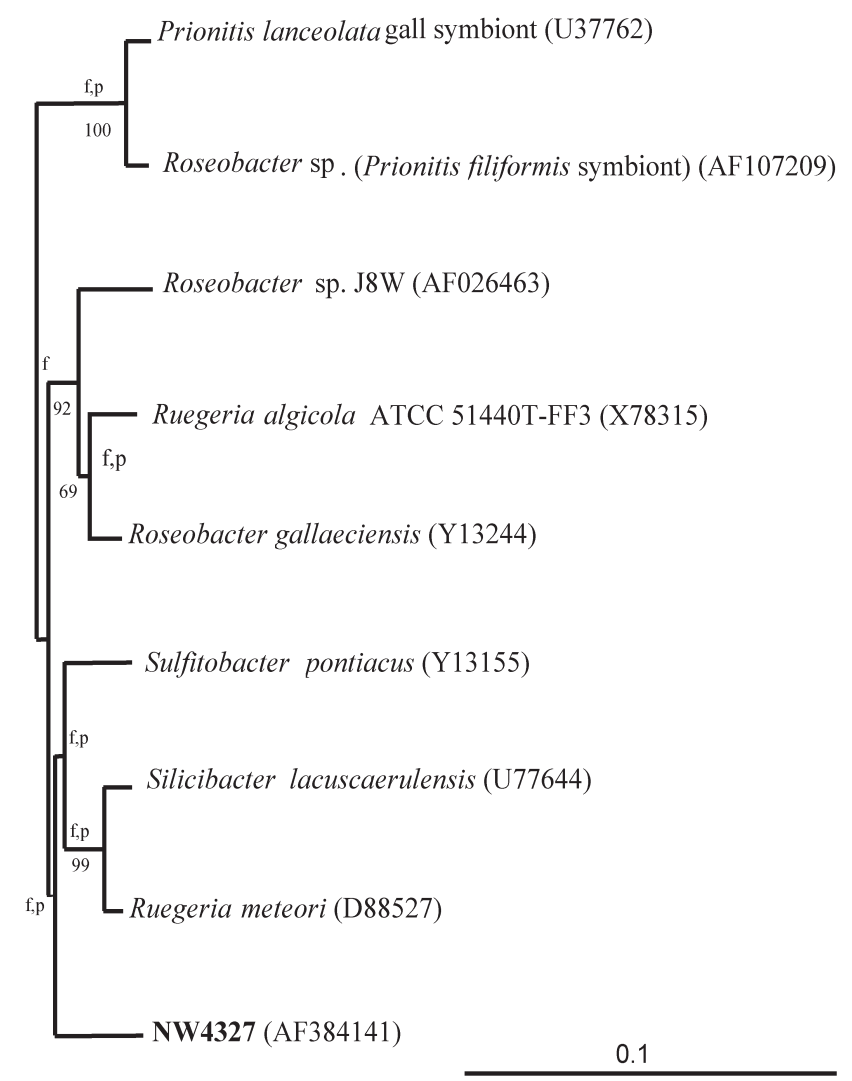

Fig. 4. Neighbour-joining phylogenetic trees from analysis of 1037 base pairs (bp) of 16S rDNA sequence from strain NW4327. $\mathrm{f}$ and $\mathrm{p}$ indicate branches that were also found using the FitchMargoliash or maximum parsimony methods, respectively. The numbers at the nodes are percentages indicating the levels of bootstrap support, based on a neighbour-joining analysis of 1000 re-sampled data sets. Only values $>50 \%$ are shown. Scale bar represents 0.1 substitutions per nucleotide position

\section{LITERATURE CITED}

Boettcher KJ, Barber BJ, Singer JT (2000) Additional evidence that juvenile oyster disease is caused by a member of the Roseobacter group and colonization of nonaffected animals by Stappia stellulata-like strains. Appl Environ Microbiol 66:3924-3930

Chavira R, Burnett TJ, Hageman JH (1984) Assaying proteinases with Azocoll. Anal Biochem 136:446-450

Gaino E, Pronzato R (1989) Ultrastructural evidence of bacterial damage to Spongia officinalis fibres (Porifera, Demospongiae). Dis Aquat Org 6:67-74

Galstoff PS (1942) Wasting disease causing mortality of sponges in the West Indies and Gulf of Mexico. Proc 8th Amer Sci Cong, p 3:411-421

Pukall R, Buntefu D, Fruhling A, Rohde M, and 5 others (1999) Sulfitobacter mediterraneus sp. nov., a new sulfite-oxidizing member of the alpha-proteobacteria. Int J Syst Bacteriol 49:513-519

Richardson L, Goldberg WM, Kuta KG, Aronson RB and 4 others (1998) Florida's mystery coral-killer identified. Nature 392:557-558 
Rützler K (1988) Mangrove sponge disease induced by cyanobacterial symbionts: failure of a primitive immune system? Dis Aquat Org 5:143-149

Sorokin DY (1995) Sulfitobacter pontiacus gen. nov., sp. nov.: a new heterotrophic bacterium from the Black Sea, specialized on sulfite oxidation. Microbiology 64:354-365

Vacelet J (1994) Control of the severe sponge epidemicNear East and Europe: Algeria, Cyprus, Egypt, Lebanon, Malta, Morocco, Syria, Tunisia, Turkey, Yugoslavia, Technical report: the struggle against the epidemic which is decimating Mediterranean sponges, FI:TCP/RAB/8853, FAO, Rome, p 1-39

Vacelet J, Gallissian MF (1978) Virus-like particles in cells of the sponge Verongia cavernicola (Demospongiae, Dictyoceratida) and accompanying tissue changes. J Invertebr Pathol 31:246-254

Editorial responsibility: Otto Kinne (Editor),

Oldendorf/Luhe, Germany
Vacelet J, Vacelet E, Gaino E, Gallissian MF (1994) Bacterial attack of spongin skeleton during the 1986-1990 Mediterranean sponge disease. In: van Soest RWM, van Kempen ThMG, Braekman JC (eds) Sponges in time and space. A.A. Balkema, Rotterdam, p 355-362

Webster NS, Hill RT (2001) The culturable microbial community of the Great Barrier Reef sponge Rhopaloeides odorabile is dominated by an $\alpha$-proteobacterium. Mar Biol 138: 843-851

Webster NS, Wilson K, Blackall LL, Hill RT (2001a) Phylogenetic diversity of the bacterial communities associated with the marine sponge, Rhopaloeides odorabile. Appl Environ Microbiol 67:434-444

Webster NS, Webb RI, Ridd M, Hill RT, Negri AP (2001b) The effects of copper on the microbial community of a coral reef sponge. Environ Microbiol 3:19-31

Submitted: September 28, 2001; Accepted: January 10, 2002 Proofs received from author(s): April 16, 2002 